This article was downloaded by: [University of Sydney]

On: 01 May 2015, At: 02:57

Publisher: Routledge

Informa Ltd Registered in England and Wales Registered Number: 1072954

Registered office: Mortimer House, 37-41 Mortimer Street, London W1T

3J H, UK

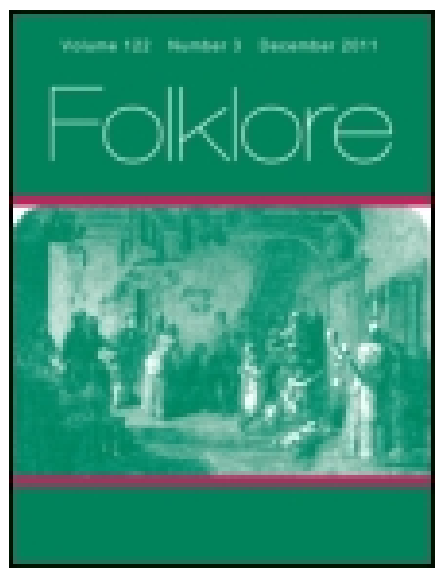

\title{
Folklore
}

Publication details, including instructions for authors and subscription information:

http:// www. tandfonline.com/loi/ rfol20

\section{The Veneration of the Cow in India.}

W. Crooke B. A.

Published online: 06 Feb 2012.

To cite this article: W. Crooke B. A. (1912) The Veneration of the Cow in India., Folklore, 23:3, 275-306, DOI: 10.1080/ 0015587X.1912.9719531

To link to this article: http:// dx. doi.org/ 10.1080/0015587X.1912.9719531

\section{PLEASE SCROLL DOWN FOR ARTICLE}

Taylor \& Francis makes every effort to ensure the accuracy of all the information (the "Content") contained in the publications on our platform. However, Taylor \& Francis, our agents, and our licensors make no representations or warranties whatsoever as to the accuracy, completeness, or suitability for any purpose of the Content. Any opinions and views expressed in this publication are the opinions and views of the authors, and are not the views of or endorsed by Taylor \& Francis. The accuracy of the Content should not be relied upon and should be independently verified with primary sources of information. Taylor and Francis shall not be liable for any losses, actions, claims, proceedings, demands, costs, expenses, damages, and other liabilities whatsoever or howsoever caused arising directly or indirectly in connection with, in relation to or arising out of the use of the Content.

This article may be used for research, teaching, and private study purposes. Any substantial or systematic reproduction, redistribution, reselling, loan, sub-licensing, systematic supply, or distribution in any form to anyone is 
expressly forbidden. Terms $\&$ Conditions of access and use can be found at http://www.tandfonline.com/page/terms-and-conditions 


\title{
THE VENERATION OF THE COW IN INDIA.
}

\author{
BY W. CROOKE, B.A.
}

(Read at Meeting, November I5th, I9II.)

ONLY those who have gained personal experience of the races of India can realize the widespread influence of the veneration of the sacred cow. In other countries, of course, we meet with instances where, like domesticated animals generally, she is the object of a profound respect, often developing into actual worship. ${ }^{1}$ For instance, in Phrygia, the slaying of an ox or the destruction of an agricultural implement was punishable with death. ${ }^{2}$ Pliny tells us that the Romans executed, just as though he had slain one of his tenants, a man who killed an ox to gratify his foolish concubine, who complained that she had never tasted tripe. ${ }^{8}$ The respect for the cow and other domesticated animals is well marked among many modern savage and semi-savage tribes, such as the Kenyahs of Sarawak, and the Herero, Bantu, Damara, and Masai in

${ }^{1}$ W. R. Smith, Lectures on the Religion of the Semites (2nd ed.), pp. 296 et seq.; E. Westermarck, The Origin and Development of the Moral Ideas, vol. ii., pp. 493 et seq.; J. Hastings, Encyclopadia of Religion and Ethics, vol. i., pp. 506 et seq. (N. W. Thomas). For Attica, Varro, De re rustica, ii. 5. 4, quoted by J. G. Frazer, The Golden Bough (3rd ed.), Part v., vol. ii., p. 6.

2 Nicolaus of Damascus, Fragm. 128, in Muller-Didot, Fragm. Hist. Graec., vol. iii., p. 461, quoted by G. Maspero, The Passing of the Empires (1900), p. 330 .

- Natural History, Bk. viii., 70. 


\section{The Veneration of the Cow in India.}

Africa. Thus, Mr. C.W. Hobley informs me,-" The Kikuyu and Kamba of East Africa, like most Africans, are attached to their cattle, but do not exhibit such an intense love for their herds as the pastoral Masai. I attribute this to the fact that the Kikuyu at any rate have not been cattleowners for such a long time as the Masai, Nandi, or Galla. The Kikuyu would fight for their cattle, but would not die en masse to prevent their capture. The Nilotic Kavirondo live on very intimate terms with their cattle. When going to an inter-tribal fight they drive a herd in front of the war party, and shout out to their opponents that if they are the better men they can try and capture the cattle. The Bantu Kavirondo drive cattle to the burial place of a chief to mourn at his grave, and they assert that the leading bullock always knows his way there." When Dr. Livingstone offered beef to some natives of South Africa, they refused to eat it because "they looked upon cattle as human and living at home like men." 5

The cow was regarded as sacred in Egypt, and the cowgoddess, Isis-Hathor, was supposed to be incarnate in an actual calf at Memphis, as Apis was in a bull ; if any one slew one of these animals by malice prepense, he was punished by death; if the offence was committed unwittingly, he was liable to any fine which the priest thought fit to impose. ${ }^{6}$ In Babylonia the ox was the representative of Ramman, the god of storm and thunder; Sin was called "the strong bull with great horns," and Athtar in

4J. G. Frazer, Totemism and Exogamy, vol. ii., pp. 355, 414; Id., The Magic Art, vol, ii., p. 212 ; Id., Taboo and the Perils of the Soul, p. 247; The Journal of the Anthropological Institute, vol. xxxi., p. 206; H. Ling Roth, The Natives of Sarawak, vol. i., pp. 388 et seq.; J. Hastings, op. cit., vol. ii., pp. 355 et seq. (E. S. Hartland).

- Missionary Travels and Researches in South Africa, p. 462.

- Herodotus, ii., 65; A. Wiedemann, Religion of the Ancient Egyptians, pp. 64, 143, 187 et seg. ; A. Erman, Life in Ancient Egypt, p. 436; W. R. Smith, op. cit., p. 302 ; J. G. Frazer, The Golden Bough (3rd ed.), Part v., vol. ii., pp. 34 et seg. 
South Arabia was incarnate in a bull; Ishtar and Ashtart at Tyre were cows. ${ }^{7}$ The sanctity of the bull among the Hittites points to a communion-link between man and God. ${ }^{8}$ In the Minoan bull cult boys and girls, according to some authorities, were devoted to be tossed by the animal, or performed perilous feats in the arena. Baal, as a god of fertility, was often represented in Palestine by a bull, like the Greek Dionysus; ${ }^{10}$ or, rather, the god was originally a bull, and only in later times lost his animal form.

At the same time, though respect for the animal is widely spread among races in the pastoral stage of culture, it seems rarely, if ever, to reach that feeling of passionate devotion towards their sacred animal which is found among the Hindus. Here devotion towards the cow appears in all the religious, domestic, and social observances of the people. Many persons keep a cow in the house as a symbol of good luck, and so arrange the position of her stall that their waking glance may fall upon its inmate; others do not eat food until they have decorated the forehead of the household cow with flowers and sandalwood paste; special festivals are observed at which the cattle are washed, adorned, and provided with dainty food; married women worship the cow to gain long life for their husbands and children, and widows in order to ensure a change in their weary lot at their next re-birth; the bull

'J. Hastings, op. cit., vol. ii., p. 313 ; G. A. Barton, A Sketch of Semitic Origins Social and Religious, p. 201.

- L. R. Farnell, Greece and Babylon, pp. 252 et seg.

'C. H. and H. B. Hawes, Crete the Forerunner of Greece, p. II6. Cf. A. Lang, Folk-Lore, vol. xxi., pp. 132 et seg.; G. Murray, The Rise of the Greek Epic, p. 127 ; ; 2nd ed., p. 5 I.

${ }^{10}$ Encyclopaedia Biblica, vol. i., cols. 63t-2; J. Hastings, Dictionary of the Bible, vol. i., p. 342; W. Ridgeway, The Origin of Tragedy, pp. 78 et seg. ; Miss J. E. Ilarrison, Themis, pp. 447 et seq. For images of the god of the Hebrews in cow form see R. A. S. Macalister, A History of Civilization in Palestine, p. 90. 


\section{The Veneration of the Cow in India.}

is worshipped before ploughing is begun, and in western India women walk ceremonially round a white cow and her red calf with a view to atone for any injury which they may at some previous time have inflicted on the animal.11

At Hindu sacred places, or even in the ordinary bazars, when the religious tension which periodically seizes all Orientals is fanned into a flame by the preaching of some fanatic, the slaughter of a cow sets the whole population in a state of frenzy. If the offence be committed by a Muhammadan it is often avenged by flinging a pig or its blood into a mosque, and then the rival sects fly at each others' throats until the authorities are able to intervene. In particular the slaughter of cows as a ritual act by Muhammadans at the Idu-'l-azha festival, which is regarded as a commemoration of Abraham's willingness to slay his son Isaac, is strongly resented, and the ill-feeling thus aroused has led to serious disturbances between gangs of rival fanatics. Only a couple of years ago dangerous riots, attended with serious loss of life, occurred at one of these celebrations in Calcutta, and in many other cities and towns it has been from time to time necessary to garrison the bazars with British troops. The prohibition of cow-slaughter has been eagerly advocated by the Hindu orthodox party; but this proposal has always been resisted on the ground that it would deprive the European population, and still more the Muhammadans and the menial classes, who are free from the taboo imposed upon the true Hindu, of an important supply of food. In some Native States, like Nepal, Rajputana, and Kashmir, and even in Burma under the late government, the killing of cows is, or

11 Gazetteer of the Bombay Presidency, vol. ix., pt. i., pp. 373 et seq.; W. Crooke, Popular Religion and Folk-Lore of Northern India (2nd ed.), vol. ii., pp. 232 et seq.; Sir J. M. Campbell, Notes on the Spirit Basis of Belief and Custom, pp. 284 et seg.; J. Tod, The Annals and Antiquities of Rajasthan (1884), vol. i., p. 63r. 
was, absolutely forbidden.12 In some places, as in Cutch, the British Government has by treaty assented to such prohibition; in other cases cession of territory was offered to it on condition that the use of beef was forbidden. ${ }^{13}$ One of the Hindu kings in the thirteenth century was forced so far to defer to Hindu feeling that he condemned the slayer of a cow to be tied up in the hide of the animal and burned to death. ${ }^{14}$ At a later period the Emperor Akbar conciliated the Jains by prohibiting the slaughter of kine at one of their chief festivals. ${ }^{15}$

On the whole, it may be said that reverence for the cow and passionate resistance to its slaughter are the most powerful links which bind together the chaotic complex of beliefs which we designate by the name of Hinduism. But, .with the curious inconsistency which meets us in the study of all oriental religions, while the cow and ox are revered, they often suffer grievous ill-treatment. The carter or ploughman will beat his team severely and torture them in various ways. A worn-out, sick animal is left to die in a ditch. This is due, partly, to the fatalism, indifference, or constitutional insensibility to pain which are characteristic of all Orientals; partly to the dread lest a merciful attempt to secure euthanasia may be visited with caste penalties and involve ritual pollution.

As a contribution to the study of the beliefs of the Hindus I propose to attempt the examination of the causes which may have contributed to establish the sanctity of the cow and bull, particularly as one of our most learned historians of India, Mr. V. A. Smith, writes, ${ }^{16}$ - "The

${ }^{23}$ W. Kirkpatrick, An Account of the Kingdom of Nepaul, p. 100; Sir W. R. Lawrence, The Valley of Kashmir, p. 286 ; J. Hastings, op. cit., vol. iii., p. 53; J. Tod, op. cit., vol. i., p. $4^{18}$.

${ }^{28}$ Gazetteer of the Bombay Presidency, vol. v., p. 158; Sir J. Malcolm, A Memoir of Central India (2nd ed.), vol. i., pp. 328-9.

14 S. Lee, The Travels of Ilon Batüta, p. 124,

${ }^{1 s}$ Sir J. Malcolm, op. cit,, vol, ii,, pp. 163-4.

10 A soka the Budahist Emperor of India (2nd edit.), p. 58. 


\section{The Veneration of the Cow in India.}

problem of the origin of the intense feeling of reverence for the cow, now felt by all Hindus, is a very curious one and still unsolved." The solution of the question which I now propose must therefore be regarded as only provisional.

To begin with the historical aspect of the subject:-The respect for the cow comes down from that ancient period when the Vedic Northerners and the Iranians still formed one united community; in other words, it probably dates from the pastoral stage, when the kinship of the herdsman with his domesticated herds was fully recognised. According to the primitive conception of kinship the unity of tribal blood extended to the flocks as much as to the people. Hence domesticated animals are often the objects of superstitious reverence, and intimacy with them tends to destroy the appetite for their flesh. ${ }^{17}$ Among the IndoAryans, as appears from the Rig-veda, the cow had already acquired a considerable degree of sanctity. She was sometimes regarded as a goddess, and the poet reminds his hearers that she is inviolable; the mother, or one of the mothers, of the god Indra was a cow. ${ }^{18}$ In the Atharvaveda, compiled at a much later period, the necessity of making over a sterile cow to a Brahman, "whom nothing hurts,"-a suggestion of a primitive taboo,- is insisted on with fierce threats against those who neglect this obvious duty ${ }^{19}$ The culture of the Indo-Ayrans, as well as that of the Iranians, both of whom were still in the pastoral stage, centred round the breeding of cattle. ${ }^{20}$ In ancient Persia it was believed that the cow alone could sustain the home

${ }^{17}$ Westermarck, op. cit., vol. ii., pp. 493, 329 et seq.

18 A. A. Macdonell, Vedic Mythology, p. 151 ; Id., A History of Sanskrit Literature, p. I09; A. Barth, The Religions of India, p. 7 ; Rig-veda, iv., I8-I.

${ }^{19}$ xii. 4, Sacred Books of the East, vol. xlii., p. 656.

${ }^{90}$ A. A. Macdonell, History of Sanskrit Literature, p. I66; W. Geiger, Civilisation of the Eastern Iränians in Ancient Times, vol. i., pp. 229 et seq. 
life of happy industry, and hence we are told that Ahura Mazda rains herbage on the earth to support her; the chief part of the reformatory work of Zoroaster was devoted to preventing the slaughter and maltreatment of cattle during the forays of the outer barbarians, the predatory tribes of the Central Asian steppe, who lived on the milk of cattle and their superfluous young. ${ }^{21}$ At the same time, it seems impossible to trace any regular cult of the cow in Vedic or Iranian times, and the passage in the Rig-veda quoted by Professor Macdonell may be merely a poetical exaggeration and not meant to suggest any actual worship.

From the earliest times down to the present the cow and her products were believed to possess special magical powers, and hence they were regarded as objects of taboo, or, as is often the case with animals and things under taboo, they were supposed to be able to remove taboo. Taboo itself generally implies, as an antecedent, what we in a vague way call "holy" or "unclean." "Things are taboo," writes Dr. Jevons, ${ }^{22}$ " which are thought to be dangerous to handle or to have to do with ; things "holy" and things "unclean" are alike taboo." When the associations which produced the feeling of "sanctity" are forgotten or misunderstood, we usually find that the idea of "holiness" attached to a person or thing is replaced by the conception that the thing is "unclean." Thus the "uncleanness" attributed to the pig in the Muhammadan world is the result of a primitive belief in the "sanctity" of the animal, which thus became the subject of taboo. ${ }^{23}$ This change of conception is well marked in the Hindu beliefs regarding the cow, her parts, and products. Such taboos are obviously part of the religious history of the race.

${ }^{21}$ A. V. W. Jackson, Zoroaster the Prophet of Ancient Iran, pp. 3r, 33; Zend Avesta, Sacred Books of the East, vol. xxxi., pp. I69 et seg.

32 An Introduction to the History of Religion, p. 59.

23 W. R. Smith, op. cit., pp. 290 et seg.; Encyclopaedia Biblica, vol, iv., cols. 4825-6. 


\section{The Veneration of the Cow in India.}

To begin with the cow, - the feeling of taboo attached to her shows itself through the whole course of the evolution of Hinduism. The respect for her, as contrasted with that felt for the bull, may be to some extent accounted for, as Professor W. R. Smith suggested, ${ }^{24}$ by the prevalence of kinship through women; but a stronger motive lay in the fact that she was regarded as the chief source of food required by a pastoral tribe. The earliest Northerners who settled in India left the work of cultivating the soil to the dark, indigenous races. This was largely due to economic considerations, the new-comers being unaccustomed to agriculture. But we may conjecture that superstition, which exercises a potent influence among primitive races, may have contributed to establish the practice. Farming was probably found to be inconsistent with the priestly functions of the Brahman because it is often closely associated with magic. Thus the ploughshare is regarded as a magical implement in the Atharva-veda, where we read for the first time of the ploughing of open fields with yokes of oxen.25 There is, again, the common belief that ploughing is a violent and dangerous intrusion upon the domain of the Earth deity. Manu, whose view is tinctured with Buddhist sentimentalism, says, in his characteristic way,- "Some declare that agriculture is something excellent, but that means of subsistence is blamed by the virtuous, for the wooden implement with its iron point injures the earth and the beings living in the earth." 26 If this consideration has any force, it may help us to understand the statement that when Prajāpati, lord of creatures, formed cattle, he made them over to the Vaisyas, whose business it became to tend them. ${ }^{27}$ The occupation of

\footnotetext{
24 Op. cit., p. 298.

${ }^{28}$ x. 6. 2, Sacred Books of the East, vol. xlii., pp. 84 et seq., 287 et seq., 356, 608 et seg.

${ }^{26} \times$. 84. Cf. L. R. Farnell, The Cults of the Greek States, vol. iii., p. 42.

${ }^{17} \mathrm{Manu}$, ix. 327, i. 90, viii. II3, x. 79.
} 


\section{The Veneration of the Cow in India. $\quad 283$}

northern India was effected by successive bodies of immigrants, among whom the Vaisyas probably retained their pastoral habits, while, by a differentiation of function, priestly duties were monopolised by the Vedic Brahmans. This furnishes an explanation of Manu's statement that those who subsist by tending, training, or selling cattle are excluded from the sacrifices offered to ancestors, and that the seller of cattle becomes a Sūdra or outcast. ${ }^{23} \mathrm{He}$ also lays down that food at which a cow has smelt is to be avoided by the Brahman, who can, however, remove the taboo by sprinkling earth upon it. ${ }^{29}$ In other words, the cow is so "holy" that the Brahman, himself the subject of rigid taboos, must be cautious in dealing with her.

Another piece of evidence pointing in the same direction appears in the custom prevailing among the Shin Dards in northern Kashmir, who, like the Kafirs of the Hindu-kush, are probably descended from the broken Northern tribes of eastern Afghanistan, driven into the hills by the advancing Muhammadans. ${ }^{80}$ They regard the cow as impure, will not eat butter nor drink milk, and, when a cow calves, they put the calf to its mother by pushing it with a forked stick, and will not touch it with their hands. ${ }^{81}$

We meet with taboos of a similar kind among the modern Hindus, even among the menial and forest tribes. The Kapilliyans of Madura keep a sacred herd, of which the cows are never milked, and the calves, when they grow up, are used only for breeding; when one of these animals dies, it is buried deep in the earth, and not given as food to menial beef-eaters, which is the usual way in which Hindus

${ }^{28}$ Ibid., viii. 102, iii. 154, 166, x. 86, 92 ; but see Gautama, xvii. 5 et seq., Sacred Books of the East, vol. ii., pp. 262 et seq.

${ }^{20} \mathrm{Manu}$, iv. 209, v. 125; Gautama, xvii. 12, ibid., p. 266.

${ }^{30}$ Sir G. S. Robertson, The Kafirs of the Hindu-Kush, p. 157.

"F. Drew, The Jummoo and Kashmir Territories, p. 428; J. Biddulph, Tribes of the Hindoo Koosh, p. 37 ; II. A. Rose, Glossary of the Tribes and Castes of the Punjab and North-West Frontier Province, vol. ii., p. 222. 


\section{The Veneration of the Cow in India.}

dispose of dead cattle ; from the herd a king bull is selected by a magical rite, and he is treated with the highest reverence. ${ }^{32}$ Siva, as a god of fertility, was originally a bull, which by the usual course of religious evolution has now been converted into his attendant or "vehicle" (vähana). Hence, when a sacred bull dies, the Devangas of southern India, who worship Siva and the bull, bury him with elaborate funeral rites; and among the Dhangars, who follow similar beliefs, a grown-up, unmarried girl, who is regarded as under taboo, is not allowed to ride on an ox, lest she pollute Basava, the sacred bull.33 Among several Hindu tribes, if a cow dies on the spot where she has been tethered, or with a rope round her neck, the whole family of the owner is taboo until they remove the pollution by bathing in a holy river; in the Punjab such an owner is sent, as a form of penance, to convey the tail of the dead cow to the Ganges, and is there beaten with a shoe by a Chuhra sweeper, a combination of indignities most grievous to a pious Hindu; among the Maratha Kunbis the mere presence of a bone of a cow or ox in the house causes its master to be temporarily excluded from caste privileges. ${ }^{84}$ The Mikirs, one of the wilder tribes of Assam, are only now under Brahman guidance beginning to give up their prejudice against keeping cows. ${ }^{35}$

Among other tribes a similar taboo attaches to the buffalo, which also possesses inherent "sanctity," probably because it has been only in comparatively recent times

${ }^{32}$ E. Thurston, Castes and Tribes of Southern India, vol. iii., pp. 219 et seg.; W. Francis, Gazetteer of the Madura District, vol. i., pp. 20 et seq.

${ }^{39}$ Thurston, op. cit., vol. ii., pp. 161-2; Gazetteer of the Bombay Presidency, vol. xxi., p. 153. Manu (iv. 142) directs that a Brahman in a state of taboo shall not touch a cow, fire, or another Brahman.

24 R. V. Russeil, Central Provinces District Gazetteers : Wardha District, vol. A, p. 60 ; Id., Bhandara District, vol. A, p. 60; Id, Sambalpur District, vol. A, p. 68; Rose, op. cit., vol. ii., p. 209.

${ }^{35}$ E. Stack, The Mikirs, p. 12 ; T. C. Hodson, The Naga Tribes of Manipur, p. II8. 
The Veneration of the Cow in India. 285

domesticated from the wild herds of the forest, the boldest and most savage of the Indian bovide. ${ }^{36}$ Hence it has been adopted as the "vehicle" of Yama, god of death-land, which lies in the south. The special Toda cult of the buffalo will be discussed later on. The Pariahs of Madras, who have no scruples about the ox, will not use a buffalo for ploughing, regard the animal as "unclean," and bathe after merely touching it. ${ }^{37}$ In the same province the wild Urālis, who eat almost any kind of meat, never dare to touch the buffalo, and the Kotas refuse to keep them. ${ }^{33}$

These facts seem to indicate that the cow and buffalo were from early times regarded as "sacred" or taboo. On the same principle the "sacred" animal removes taboo. In the Wardha district, when a child is born at an inauspicious time, it is tied between two winnowing fans bound together with a new rope, and a cow is made to lick one of the limbs of the child, a rite which is supposed to remove the ill-luck attaching to its birth. ${ }^{89}$

In the same connection the taboo of milk is interesting and instructive. We find this taboo in force among pastoral and agricultural tribes beyond the Indian area. Most of the Central African negroes regard the drinking of milk with aversion; some of them do not allow women to have anything to do with milk or cattle, and others, when they drink milk, do not use it fresh, but curdled. ${ }^{40}$ Major A. J. N. Tremearne tells me that the Filani of North Nigeria object to sell fresh milk, and, as a rule, they will not drink it. If they do sell fresh milk, they always pour a little out of each calabash on the ground. In other words, like all

${ }^{86}$ W. T. Blanford, The Fauna of British India, etc. : Mammalia, p. 493.

37 L. K. Anantha Krishna Iyer, The Cochin Tribes and Castes, vol. i., p. 85.

86 Thurston, op. cit., vol. vii., p. 247 ; Travancore Census Report, 1901, vol. i., p. 35I ; II. B. Grigg, A Manual of the Nilagiri District, p. 203.

${ }^{30}$ R. V. Russell, op. cit.: Wardha District, vol. A, p. 78.

* Sir HI. H. Johnston, British Central Africa, p. 43I. 


\section{The Veneration of the Cow in India.}

first-fruits, it may be used only with careful precaution, and this may supply a better explanation of similar Indian customs than if we suppose it to represent an offering to Mother Earth." "When this article of food acquires considerable value, both because of its practical importance and because of the primary adjustments necessitated in caring for it, situations repeatedly arise which necessitate secondary adjustments in order that due regard may be shown to the pre-existing sanctity, or in order that it may be preserved intact in the new relations, or that no injury may come to its possessors when its sanctity is in a way violated, as, for instance, when it is removed from its accustomed environment. These secondary processes, designed to preserve its value, not only accomplish that end, but even greatly enhance it." 42

The prevalence of the milk taboo among tribes scattered over a wide area in India suggests that at one time it may have been almost universal. It is at present not found in those regions most completely under Brahman influence, and its disappearance here may have been due to the use of milk in offerings to the gods in lieu of animal sacrifices, to Brahman objection to customs of the indigenous tribes, or to some economic consideration which we do not at present understand. At the present time we find the taboo in force among some of the Indo-Chinese races, among isolated tribes along the Himalaya, or at its foot, and among some peoples in central and southern India.

Beginning from the extreme north and west, it prevails among the Dards of Kashmir, who are now only just beginning to overcome it since they have come under the

1 A. J. N. Tremearne, The Tailed Head-Hunters of Nigeria, p. 243; Sir D. Ibbetson, Punjab Ethnography, p. II4; R. V. Russell, Central Provinces District Gazettecrs : Damoh District, vol. A, p. 54 ; cf. the rite of making an oblation of wine at the Greek Pithoigia, "so that the whole may be released from tabu," Miss J. E. Harrison, Themis, p. 277.

Q I. King, The Development of Religion, pp. 120 at seq. 
rule of Islam. ${ }^{43}$ In Assam the Khāsis, Kachāris, Rabhas, Gāros, Nāgas, and Daphlas all regard milk as "unclean," and the Kükis do not milk their cattle.4 Mr. T. C. Hodson, however, tells me that in Meithei there are two terms, namungba, "forbidden with a quasi-automatic sanction," and haondaba, "unusual, not customary." "If a Meithei told me that such and such a thing was namungba, I took him to mean that, if he did or ate the thing, he would suffer for it, in fact, that the sacred element would work against him. But if he did what was not customary, I see no sanction beyond the feeling that, as L. T. Hobhouse, (Transactions of the Third International Congress for the History of Religions, vol. ii., p. 435) put the case, for the individual, custom has something of the force of habit and more than habit. The abstinence from milk, both of cows and buffaloes, is general, yet they eat freely of the flesh of cattle." Here the taboo has crystallised into custom. In the Punjab milk and ghi or clarified butter made from it are subject to the usual taboo attaching to first-fruits. After a cow has calved, the Batwāls do not eat $g h i$ until some has been offered to a Brahman; the Kaler Jats give the first milk of a cow or buffalo to a virgin, and, if it be abundant, to other girls as well, these people being free from the risk of violating the taboo. ${ }^{45}$ In the same province a Khatri mother never drinks milk after the birth of a child. ${ }^{46}$ In the hill country south of the Ganges, the Savaras, though they hold milk in abhorrence, use it in offerings to their gods. ${ }^{47}$ The Kols and Hos plough with cows as well as oxen, but they make no other use of the cow, and Dr. Ball found it difficult

43 Ghulam Muhammad, Memoirs Asiatic Society, Bengal, vol. i., p. 94 ; F. Drew, op. cit., p. 428.

"P. R. T. Gurdon, The Khasis, pp. 51, 159; S. Endle, The Kachdris, p. 15 ; T. C. Hodson, The Naga Tribes of Manipur, p. 182; A. Playfair, The Garos, p. 50; T. H. Lewin, The Hill Tracts of Chittagong, p. 104.

is H. A. Rose, op. cit., vol. ii., pp. 68, 439.

sbid., vol. ii., p. 525.

17 Thurston, op. cit., vol. vi., p. 334 . 


\section{The Veneration of the Cow in India.}

to procure milk in their country because the cows were never milked. 48

The same is the case with the Indo-Chinese races, like the Burmans and Shans, the latter using milk only for medicine, and not for food, regarding its taste as unpleasant and its smell as disgusting. ${ }^{49}$ The same feeling prevails in Java and Sumatra, and in Bali, where Hinduism still prevails, the people use coco-nut liquid instead of $g h i$ in offerings to their gods, though some Pandits are now beginning to make ghi out of milk. ${ }^{50}$ One tribe of Malay hereditary bards will not touch milk, and, when M. Grandjean told the Laos of Siam that Europeans liked and used milk, they laughed, and from that time held his countrymen in contempt. ${ }^{51}$

It is a question deserving investigation whether the IndoChinese races brought this taboo with them from their original home, because, if this be the case its appearance in India and its borderlands may turn out to be a fact of some ethnological importance. Hence it is relevant to push the enquiry beyond the Himalaya. In Tibet custom seems to vary, the people in the neighbourhood of Lhasa never drinking milk, while in the western districts, probably through Hindu or Buddhist influence, there seems to be little objection to its use.62 The late Sir H. Yule, a firstrate authority, asserted that the Chinese do not use milk. ${ }^{53}$ The evidence is not quite conclusive, but I am indebted to Lieut.-Col. L. A. Waddell and Professor E. H. Parker for

49 E. T. Dalton, Descriptive Ethnology of Bengal, p. 195; V. Ball, Jungle Life in India, pp. 165 et seq.

${ }^{49}$ Mrs. L. Milne, The Shans at Home, p. 48.

so Sir H. Yule, The Journal of the Anthropological Institute, vol. ix., p. 290.

${ }^{51}$ W. W. Skeat, Malay Magic, p. 673; Sir J. Bowring, The Kingdom and reople of Siam, vol. ii., p. 12.

${ }^{62}$ L. A. Waddell, Lhasa and its Mysteries (3rd ed.), p. I72; C. A. Sherring, Western Tibet and the British Borderland, p. 298; S. Turner, An Account of an Embassy to the Court of the Teshoo Lama, in Tibet, pp. 188, 195.

${ }^{33}$ See note 50 supra. 


\section{The Veneration of the Cow in India. 289}

some information on the subject. The latter writes,"There was never a true milk taboo in China, for no one ever dreamed of drinking it. The very word 'cow's milk' appears only in the fifth century of our era, when a man under the Tartar dynasty has a 'girl-like' complexion because he drank cow's milk habitually. The Chinese, to a man, eat fat pork and eggs, whence, I suppose, they get their fat and albumen." Thus we seem to find that in early Chinese times milk was never used. This prejudice, however, seems now to be disappearing. Lieut.Col. Waddell remarks that during the war which followed the Boxer rising in 1900-I90I he was much struck by the absence of milk and butter from the dietary of the people. But during our occupation of Peking tinned milk was imported for the rations of the European troops, and, after a short time, the Chinese began to beg or purchase it for their own use. Dr. Wells Williams ${ }^{54}$ states that, while the Manchu Empress used to receive the milk of twentyfive cows daily, butter and milk were little used by the Chinese themselves. He tries to account for this on the ground that in this closely cultivated country there is little room for cattle. But in northern India, where the land is covered with crops, numbers of milch cattle are supported by stall-feeding. Another explanation of the non-use of milk on the Steppe is that koumis, the drink usually prepared from mare's milk, cannot be made from that of cows. ${ }^{55}$

It is, however, among the Todas, whom Dr. Rivers, with much probability, identifies with the Nambutiri Brahmans and Nayars, races which preserve their primitive rites in greater purity than the northern Hindus, that we find the milk taboo most rigidly enforced. The basis of the Toda rites, which are more or less common to their neighbours

st The Middle Kingdom (4th ed.), vol. i., pp. 219, 319; vol. ii., pp. 46 et seg.

s5 F. Ratzel, The History of Mankind, vol. iii., p. 330. 


\section{The Veneration of the Cow in India.}

the Badagas, Koravas, and Kotas, ${ }^{56}$ is the danger of dealing with such a "sacred" substance and the removal of taboo.57 Dr. Rivers supposes that in former times the milk of the sacred cattle, which can now be used under careful restrictions, by the herdsmen and some members of the tribe, was reserved for the calves, a rule which in certain cases still holds its ground. ${ }^{58}$ At present the milking-place and the dairy are carefully screened from public view ; no woman is permitted to enter them; no widower or widow is allowed to drink the milk during the period of mourning; the dairy is regarded as a temple, and the dairyman is protected by rigid taboos. ${ }^{59}$ The wilder section of the Veddas apparently never kept cattle, and their shamans do not object to drink milk. In some places it is believed that the presence of cows in the house neutralises the polluting influence of women on the sacred objects of the tribe. ${ }^{60}$

The magical properties attributed to milk in south India are shown by its use for the removal of taboo. The Tottiyans pour milk over the married pair, and the Tiyans remove the death pollution by letting some drip on the heads of the mourners. ${ }^{61}$ The same feeling attaches to other products of the cow. The value of her urine as a means of removing taboo was well established among the Iranians. ${ }^{62}$ In India the use of the same substance can be traced back to the Atharva-veda, and is probably much older, while from the period of the law-books down to the

${ }^{60}$ Thurston, op. cit., vol. i., pp. 75, 88; vol. iii., pp. $49 \mathrm{I}$ et seg.; vol. iv., pp. ro et seg.

"77 W. H. R. Rivers, The Todas, p. 23I ; J. G. Frazer, The Golden Bough (3rd ed.), Part v., vol. ii., p. 3I4.

"sivers, op. cit., pp. 231 et seq., 24I, 245. B9 Ibia., pp. 430, 241.

${ }^{60}$ C. G. and B. Z. Seligmann, The Veddas, pp. 48,178 et seq.

o1 Thurston, op. cit., vol. vii., pp. 192, 87.

"M. Haug, Essays on the Sacred Language, Writings, and Religion of the Parsis (2nd ed.), pp. 242, 331, 385; Zend Avesta, Sacred Books of the East, vol. iv., pp. $64,98,216$. 
present day its efficacy is fully recognised. ${ }^{\theta 3}$ The use of the dung for like purposes dates from an equally early period. ${ }^{64}$ The hide of the bull, like the sheepskin used at Roman marriages, imparts fertility to the bride. According to the Vedic ritual she has to sit on the hide of a red bull with the hair upwards as soon as the stars appear in the sky. ${ }^{65}$ In the Atharva-veda, as a charm to cure jaundice the priest makes the patient sit on the hide of a red bull in order to attract, by a process of sympathetic magic, its redness to counteract the yellowness characteristic of the disease. ${ }^{66}$

From the facts thus stated it appears that the respect paid to the cow dates from a very early period, probably from the pastoral age. We have now to consider the further problem : How can this feeling of respect be reconciled with the habitual sacrifice and the use of beef as food in the Vedic age, and even down to a much later period?

It is now admitted that in early times the cow was sacrificed at various rites, such as the consecration of a king and in the worship of the gods. In Vedic times a special word, goghna, "one for whom a cow is slain," is used to designate a guest. ${ }^{67}$ The heroes of the Mahābhārata habitually ate beef, and Vedic texts are cited to justify the

${ }^{63}$ Atharva-veda, Sacred Books of the East, vol. xliii., p. 489 ; Manu, xl., 166.

"4 Vishnu, Sacred Books of the East, vol. vii., pp. 96, 105, 260; Sir J. M. Campbell, op. cit., pp. 39 et seq., 407.

os 11. T. Colebrooke, Essays on the Religion and Philosophy of the Hindus (1858), p. 139 ; J. G. Frazer, Totemism and Exogamy, vol. iv., p. 210.

os Sacred Books of the East, vol. xliii., p. 263.

"1 A. A. Macdonell, Vedic Mythology, p. I51; Id., History of Sanskrit Literatuve, pp. 149, 162 ; A. Barth, op. cit., p. 35 ; F. Max Muller, Hibbert Lectures: Lectures on the Origin and Growth of Religion (1878), p. 35I; Atharva-veda, - Sacred Books of the East, vol. xliii., pp. 226, 228. The custom is said to have been discontinued in the eighth century of our era by the reformer Sankarăchărya, who substituted for it the "honey offering" (madhuparka), Gaxetteer of the Bombay Presidency, vol. xxiv., p. 77 ; and see Manu, lii., 119, v. 4 r. 


\section{The Veneration of the Cow in India.}

practice. $^{63}$ Even when Buddhism became the state religion we constantly hear of butchers and slaughter-houses; and in the folklore of that age, as well as in the collection of tales made by Somadeva, which are full of the spirit of Buddhism, similar evidence is forthcoming. ${ }^{69}$ Thus we read in the Buddhist Jataka of Hindus observing the home worship of the cow, and at the same time of a Brahman who proposes to sacrifice a cow to Agni, the fire-god; some tax-gatherers kill a calf to make a sword-sheath out of its skin; peasants eat an $o x$ in time of famine, all these practices being apparently usual and not subject to censure. ${ }^{70}$ I am indebted to Mrs. Rhys Davids for a note on the position of the cow in Buddhist literature. She finds no evidence in the Pitakas that the animal was held in special regard by Brahmans, Buddhists, or any other class. She has so far come across no evidence showing the growth, subsidence, or recrudescence of cow-sanctity in the Pitakan literature. Buddhists and Jains would be no more averse to the slaying of cattle than that of any other creature.

At the same time, during the period marked by the decay of the early Brahmanism and the rise of Buddhism, we see the gradual rise of a humanitarian movement with the object of restricting or abolishing animal sacrifice. The origin of this movement is obscure. Some authorities have tried to connect it with the rise of the doctrine of metempsychosis, which was as little known to the Vedic tribes as it was to the Iranians, appearing first in the Brahmana period. ${ }^{71}$ At the same time, transformation into

${ }^{68}$ E. W. Hopkins, The Religions of India, p. 365 .

"T. W. Rhys Davids, Buddhist India, p. 93 ; H. C. Warren, Buddhism in Translations, p. 360 ; Sumadeva, Kathā sarit sägara (ed. C. H. Tawney), vol. i., pp. 227, 241 .

${ }^{70}$ The Jātaka (Cambridge Translation), vol. ii., p. 156; vol. i., p. 308; vol. v., p. 57 ; vol. ii., p. 94 .

$"$ A. Weber, The History of Indian Littrature, p. 73; A. A. Macdonell, History of Sanskrit Literature, pp. I1 5, 223, 386, et seq.; A. Barth, op. cit., p. 78 ; M. Haug, op. cit., p. 15 . 
animals is familiar to most men of the lower culture, and is in many cases misinterpreted so as to include metempsychosis. ${ }^{72}$ It is probable that the influence of metempsychosis has been exaggerated. It was certainly current in the philosophical schools, but it seems to have had little effect upon the masses of the people. Even Manu, who expounds its principles at length, speaks of it as a "progress hard to be understood by unregenerate men." 73 At the present day in Burma, where it is generally accepted, it has as little effect in securing the kind treatment of animals as in modern India. ${ }^{74}$ As Mr. Hopkins remarks, ${ }^{75}$ "It is surely not because the Hindu was afraid of eating his deceased grandmother that he abstained from eating beef." Two causes seem to have led to the gradual disuse of animal food:-the fear of absorbing through the blood the rational soul of the animal; the old idea still retaining force that the tribal blood ran in the veins of the domesticated animals. ${ }^{75 *}$ It is possible that the humanitarian movement was the result of a change of environment which weakened the moral fibre of the Northern race, and that increasing material culture, with its opportunities for leisure, encouraged the growth of that morbid introspection and sentimentalism which characterise all decadent communities.

However this maybe, the writers of this age of transition are obviously embarrassed in their search for an explanation of these divergent views, which recognised the use of the animal as a sacrificial victim, and at the same time encouraged its protection. Manu, for instance, promises

72 E. S. Ilartland, Primitive Paternity, vol. i., pp. 156 et seg., and especially pp. 246 et seg.

72 xii., I et seg.; vi., 73.

"Capt. C. J. F. S. Forbes, British Burma and ils People, p. 321.

"Op. cit., pp. 199 et seq. The Egyptians, who worshipped the ox, did not believe in migration of souls in the Indian sense. Encyclopadia Biblica, vol. ii., col. $1218 n$.

76* Encyclopadia Britannica (1th ed.), vol. ii., p. 718 . 


\section{The Veneration of the Cow in India.}

heavenly bliss to him who injures no living creature, and reprobates all animal slaughter, and in particular the killing of kine. But he evades the difficulty by pleading that the killing of beasts for sacrifice is not slaughter in the common sense of the word; he permits a twice-born man to kill animals for sacrifice and for the entertainment of a guest; and, in a very feeble way, he excuses such practices on the ground that herbs, trees, and animals used for sacrifice "receive, being reborn, higher existences." 78 This theory is justly satirised by a writer in the Buddhist Jātaka. ${ }^{77}$ But it persists in modern times, the degraded Buddhist monks of Tibet, when they eat flesh meat, repeating a charm which ensures that the animal shall be reborn in heaven..$^{78}$ Manu sums up the matter by admitting that there is no sin in eating meat, "but abstinence brings great rewards"; and he allows a form of commutation, ordaining that, when a man desires meat, he may make an animal out of butter and eat it. ${ }^{79}$

The same difficulty in reconciling these conflicting views has been felt by modern Hindus. Some forty years ago a paper by a learned Hindu scholar, Dr. Rájendralála Mitra, entitled "Beef in Ancient India," 80 in which he described the use of the sacred animal for food, caused much astonishment and alarm. From it the inference was drawn that beef-eating, due to mere sensual appetite, was as common in ancient India as it is in many other countries at the present day. This belief, I venture to think, is unfounded, and rests upon a mistaken view of the intention with which the animal was killed and eaten.

It is now almost a commonplace that many pastoral and agricultural tribes kill and eat their sacred animal as a

70 iv., 246 ; xi., 69, 7I, 60; v., 39 et seg., 56; iii., 267 et seq. $\quad 77$ vi., IO.

${ }^{78}$ L. A. Waddell, The Buddhism of Tibet, p. 216 . "7v., 37, 56.

${ }^{80}$ Republished from The Journal of the Asiatic Society of Bengal in Indo. Aryans, vol. i., pp. 354 et seq. Cf. Romesh Chunder Dutt, History of Civilisation in Ancient India, vol. i., p. 4I. 
means of gaining communion with the divine. It is unnecessary to discuss the explanations of this rite which have been given by Professor W. R. Smith and MM. H. Hubert and M. Mauss, ${ }^{81}$ and, though the original theory of the totem sacrament no longer retains the authority which it once possessed, ${ }^{82}$ it preserves sufficient vitality to assist in the interpretation of the Hindu evidence. It is at least clear that in ancient India the sacred animal was killed and its flesh eaten, not from the mere craving for beef, but as a ritual act.

This inference is strengthened by a consideration of the rites of two tribes which retain in a remarkable degree their archaic practices,-the Kafirs of the Hindu-kush and the Todas.

As regards the Kafirs, we lack distinct evidence that they regarded the cow as specially sacred. But they display extreme affection towards their domesticated animals, and the confidence which the animal showed to his master made their slaughter a comparatively easy matter. Their goddess Krumai appeared in the form of a goat; they carve the heads of goats, cows, and rams on their temples; the cow is the unit of value in the assessment of fines for

"1 W. R. Smith, op. cit., pp. 218 et seg.; J. G. Frazer, The Golden Bough (2nd ed.), vol. ii., pp. 365 et seq.; L'Anné Sociologique, vol. ii., p. 93, reviewed in Folk-Lore, vol. xi., pp. 92 et seg.; L. R. Farnell, Greece and Babylon, pp. 235 et seq. For the bull sacrifice amongst the Celts see J. A. MacCulloch, The Religion of the Ancient Celts, p. 149. Cows are sacrificed in China, according to J. J. M. De Groot, The Religion of the Chinese, p. 105. See also, for similar rites in Kashgar, J. G. Frazer, The Golden Bough (3rd ed.), Part v., vol. ii., p. I3 $n$.

22 F. B. Jevons, The Idea of God in Early Keligions, pp. 60 et seg. The most recent theory discards the idea that the sacred flesh is shared with the God. "In sacrifice the factors were only two, the eater and the eaten, the 'worshipper,' that is the eater, and the sacred animal consumed. Once the sacred animal consumed, his mana passes to the eater, the worshipper, and the circuit is complete. There is no third factor, no god mysteriously present at the banquet and conferring his sanctity on the sacred animal." Miss J, E. Ilarrison, Themis, p. 136. 


\section{The Veneration of the Cow in India.}

tribal offences. ${ }^{83}$ They were in race akin to the Northern stock, and the inference that they, too, respected the cow is more than probable. Yet these people until quite recently, when they were converted to Islam, used to sacrifice bulls to Gish, their war-god, and cows to Imra ; when peace was made by settling the blood price after a homicide, the representatives of the rival clans used to dip their feet in the blood of a cow slain for the occasion. The flesh of the sacrificed animals was freely eaten. ${ }^{84}$

The case of the Todas is still more clear. They eat ceremonially at one of their festivals a young buffalo, which is their sacred animal. ${ }^{85}$ Still more significant is the fact that they raise a wail at the death of the beast, as the women of Nestor's house did when the ox, the sacred family animal, was slain, though Homer's women do not lament when cattle captured from the enemy are slaughtered..$^{80}$ The cry in this case is not, as some commentators allege, one of exultation, nor an expression of sorrow. It is a ritual act to disperse evil influences from the stream of "our brother's" sacred life. ${ }^{87}$ The Todas are also careful to prevent the blood of the sacred animal being shed at the time of sacrifice, and the death of the victim is procured by crushing a vital organ in a most cruel manner, a fact which was familiar to the early Greek

${ }^{88}$ Sir G. S. Robertson, The Kafirs of the Hindu-kush, pp. $384,391,444$; cf. Tacitus, Germania, xii.

BS Sir G. S. Robertson, op. cit., pp. 189-90, 636, 405, 389, 442.

${ }^{86}$ Rivers, op. cit., p. 274; J. W. Breeks, An Account of the Primitive Tribes and Monuments of the Nilagiris, p. 9.

80 Rivers, op. cit., p. 356; Homer, Odyssey, Bk. iii., ll. 450 et seq.; with Merry-Riddell's note in loc. Compare the ceremonial flight at the Bouphonia, J. G. Fraser, The Golden Bough (and edit.), vol. ii., pp. 294 et seg. ; Id., Pausanias, vol. ii., pp. 303 et seq.; Miss J. E. Harrison, Prolegomena to the Study of Greek Religion, pp. II I et seq.; L. R. Farnell, The Cults of the Greek States, vol. i., pp. 56 et seq., 88 et seq.

"G. Murray, The Rise of the Greek Epic (2nd ed.), Pp. 86 et seg. 
writers, and the same rule was followed in the ancient Brahmanical sacrifice, as is still the case among the modern Brahmans of south India and some of the forest tribes. ${ }^{88}$ So, according to the Vedic sacrificial rule, the priest, while slaying the victim, took care to avert his eyes, and after the animal was killed he called out,-" Far may be the consequences of murder from us!" 89

Survivals of this custom of eating the sacred animal after sacrifice, or an image of the god, are still found among some of the Indian tribes. The semi-Hinduised Gonds, who, like all converts, are careful about ritual observances, carry their dread of pollution so far as to have their faggots sprinkled with water before they are used in cooking, and, if at dinner-time a Brahman or a "crow," both regarded as "sacred" or taboo, approach, the whole of the food is considered polluted and thrown away. Yet these people are compelled, every four or five years, to visit the shrine of Bara Deo, their tribal deity, and in his presence they are forced to eat the meat of a sacrificed cow, as a sacramental meal. But, as a compromise, they now make only a pretence of eating it, merely touching it after holding a cloth before their mouths.90 The Darzis or tailors of Kathiawar are considered by their neighbours impure because, at their marriage feasts, they offer and probably eat, as a communal act, the image of a cow made of molasses.1 One clan of Bhils make an image of a

\footnotetext{
${ }^{88}$ Rivers, op. cit., pp. 288, 278 et seg. ; Strabo, xv., 54 ; Abbé Dubois, Hindu Manners, Customs, etc. (3rd ed.), p. 510; M. IIaug, The Aitareya Brahmanam, vol. ii., p. 85; L. F. Begbie and A. E. Nelson, Gazetteer of Chanda District, vol. i., p. 132; R. V. Russell, Gasetteer of Nimar, vols. i., iii. On the custom of strangling sacrificial animals see J. G. Frazer, Adonis, Atiis, Osiris (2nd ed.), p. 404.

"H Haug, op. cit., vol. ii., p. 89; Satapatha Brahmana, vol. iii., pp. 8, 1, 15.

$0 \mathrm{~S}$. Hislop, Papers relating to the Aboriginal Tribes of the Central Provinces, p. 5 ; Sir C. A. Elliott, Settlement Report of the Hoshangabad District, p. 69.

11 Gazetteer of the Bombay Presidency, vol. ix., pt. i., p. 503.
} 


\section{The Veneration of the Cow in India.}

dog, their sacred animal, in flour, and eat it. They have invented an aetiological legend to explain the practice, asserting that one of their ancestors once ate a puppy by mistake for a hare. ${ }^{92}$ The Komatis of Madras make an image of a cow in flour, cut it up with implements shaped like those used by the beef-eating castes, and distribute, according to a fixed rotation, joints of the image to certain families. ${ }^{93}$ At a wedding among the Malas of the same province an image of their tribal goddess, Sunkalamma, is made of rice and gram; offerings are laid before it, and a ram or he-goat is sacrificed; the worshippers prostrate themselves in silence, and then divide and eat the goddess. ${ }^{94}$ This ceremonial distribution of the joints of the victim was a rule in the old Hindu sacrifices, and, when it was described by Dr. Rájendralála Mitra, was a shock to modern orthodox Hindus. ${ }^{95}$ The same rule was in force among the Semites and the Greeks of Cos. ${ }^{96}$ At the death feast of the Assam Nāgas there are equally precise rules for the distribution of portions of the victim among the relatives of the dead man and the family priest.97

As was the rule among the Semites, the early Hindu law-givers directed that the flesh of the victim, after dedication, might be eaten, and this rule is still in force among various Indian tribes. For instance, the flesh of the Toda victims is openly sold in the bazars. ${ }^{98}$ It is still more remarkable that such food is permitted to two tribes of

"Capt. C. E. Luard, Ethnographical Survey of Central Iudia, p. 69.

's Thurston, op. cit., vol. iii., pp. 329 et seq.

" lbid., vol. iv., pp. 357-8.

${ }^{95}$ Rájendralála Mitra, op. cit., vol. i., pp. 373 et seq.; Haug, op. cit., vol. ii., pp. 44 I et seq.

${ }^{96}$ W. R. Smith, op. cit., pp. $34 \mathrm{I}$ et seq. ; J. G. Frazer, Pausanias, vol. iii., p. 551.

"7 T. C. Hodson, The Näga Tribes of Manipur, pp. I49 et seq.

${ }^{98}$ Rivers, op. cit., p. 285 ; Vishnu Purana (ed. H. H. Wilson, 1840 ), pp. 306 et seq. 


\section{The Veneration of the Cow in India. 299}

Brahmans who are notoriously careful in their ritual observances. The only occasion on which the Nambutiri Brahmans of Malabar eat meat is when, as part of a solemn rite on recovery after sickness, they eat the flesh of a sacrificed goat. ${ }^{99}$ The Deshasth Brahmans of the Deccan are ordinarily vegetarians, except when, at long intervals, they eat the residue of a goat offered in sacrifice. ${ }^{100}$ In these cases the goat has probably replaced the older cow victim. In Mysore and other parts of India high-caste Hindus seldom eat animal food except that of victims offered in sacrifice. ${ }^{101}$ The Kolis, a low Punjab tribe, do not touch beef, but they gladly eat the flesh of a buffalo which has been offered to one of the goddesses. ${ }^{102}$ In Bengal goats and sheep sacrificed in immense numbers to the goddess Durga are eaten by Brahmans. ${ }^{103}$ A modern Hindu, who protests strongly against such practices, writes: "In these later ages, when degeneracy has made rapid strides amongst the people of the country, the original intention of the founder of the institution [of sacrifice] being lost sight of, a perverted taste has given it an essentially sensual character. Instead of offering sacrifice from purely religious motives, it is now made for the gratification of carnivorous appetite." 104

We thus arrive at the conclusion that the eating of the "sacred" flesh is an act of ritual, a form of the communal sacrifice. I proceed to suggest an explanation of the modern fanatical veneration of the cow.

"Thurston, op. cit., vol. v., p. 235.

100 Gazetteer of the Bombay Presidency, vol, xvii., p. 51.

${ }^{101} \mathrm{~F}$. Buclianan, A Journey from Madras through the Countries of Mysore, Canara, and Malabar, vol. iii., p. 107.

102 II. A. Rose, op. cit., vol. ii., p. 554.

${ }^{103} \mathrm{~W}$. Ward, A View of the History, Literature, and Religion of the Hindoos (2nd ed.), vol, ii., pp. III-4.

${ }^{104}$ Shib Chunder Bose, The Hindoos as they are, pp. 104-5; cf. W. R. Smith, op. cit., p. 354 . 
We have seen that the dogma of metempsychosis offers no adequate explanation of the growth of this sentiment in its present exaggerated form. The same may be said of totemism. Dr. Frazer has now come to the conclusion that "the prohibitions to eat the flesh of horned cattle and deer seem to be too general to be totemic; since a characteristic feature of true totemism is that its taboos are observed not by whole tribes or communities but only by particular stocks or families which compose the tribe or community." 105 Further, he admits that the attempt to find totemism among the so-called Aryan races is unsuccessful.106 In the almost exhaustive lists of totems in India, which his industry and research have accumulated, it is remarkable how infrequently the cow or buffalo appears. ${ }^{107}$ Domestic animals are rarely selected as totems, and the absence of cow or buffalo totems in India indicates that this institution can have exercised little influence on the present problem.

More is to be said in favour of the commonly accepted theory, which has the support of Mr. Hopkins, ${ }^{108}$ that the movement for the protection of kine was based upon economical considerations, the ox being essential to agriculture, the chief industry of the Hindus. It cannot be denied that this may have had some effect, and this feeling doubtless largely accounts for the respect paid to the animal in the pastoral stage of culture; and at present all Hindus accept this as the explanation of their devotion to the animal. But it may be urged that, while this feeling may in some measure account for the respect paid to the animal, it cannot account for the existing fanatical reverence. Experience of the Hindu and other backward races shows that economical or hygienic considerations exercise

${ }^{205}$ Totemism and Exogamy, vol. ii., p. 204.

108 Ibid., vol. iv., pp. 12 et seq.

${ }^{107}$ Ibid., vol. ii., pp. 218 et seg.

108 Op. cit., p. 200. 
only an intermittent influence. Such races are swayed rather by magic, by other forms of superstition, or by hereditary custom.

The reverence for the cow must therefore, I venture to think, be based on some feeling which is in its nature religious rather than economical or hygienic. We seem thus to be compelled to seek an explanation in causes connected with the race origins or religious beliefs of the Hindus.

Two prominent facts underlie the whole history of the evolution of Hinduism: first, the conflict between the Northerners and the races which they found in possession of the land; second, that between the Brahman or priest and the Kshatriya or warrior tribes. It is significant that the question of the cow appears prominently in both these conflicts.

The early Northerners were exposed to constant raids, in which their cattle were captured by the Dasyus or aboriginal people, and the former retaliated by seizing the herds of their adversaries. The graphic account of the situation by Dr. J. Muir explains all the facts. ${ }^{109}$ The whole situation must have tended to bring the question of the protection of their herds into prominence.

Secondly, we have the contest between the priestly and warrior elements in the Vedic community. ${ }^{110}$ The importance of this in relation to the social and religious evolution of the Hindus we are only now beginning to realise.

During the period represented by the Brahmana and law literature the cow came to be closely associated with the Brahmans. The appropriate fee for the performance of all religious duties was one or more cows, and many tales are told of princes offering gifts of enormous numbers of cows

${ }^{109}$ Original Sanskrit Texts on the Origin and History of the People of India, their Religion and Institutions, Pt. ii., pp. 409, 407, 395, 406, 400.

110 lbid., Pt. i., pp. $5^{8}$ et seg. 


\section{The Veneration of the Cow in India.}

to their priests. ${ }^{111}$ In the preface to the Mahäbhārata ${ }^{112}$ we are told that "this collection of all sacred texts, in which the greatness of cows and Brahmans is exalted, must be listened to by virtuous-minded men." Manu lays down that he who dies, without expectation of reward, for the sake of Brahmans and cows, secures beatitude even for the outcasts of the community, and the kindred of such heroes do not incur the death pollution. ${ }^{113}$

It is now fully established that the ranks of the Kshatriyas or warriors were recruited by the admission of many Scythian and Hun princes, who in the troubled times between the second century B.C. and the sixth century of our era successively invaded and occupied northern India. ${ }^{114}$ As a natural result of this entry of cow-killing and beef-eating foreigners we hear many tales of outrages committed on the wonder-working cows of Brahman ascetics by these new-comers. ${ }^{115}$ The law books denounce such offenders in the most savage terms. ${ }^{110}$ These strangers, finding that the habit of eating beef as a ritual act was prevalent among the Hindus, were naturally encouraged to believe that their own hereditary practices were not inconsistent with the Hindu faith which they now adopted.

The result of these two conflicts, in which the plunder and slaughter of cattle were largely involved, must have tended to identify more and more closely the Brahman Levites with the animal which they were already pledged to protect and reverence. From this we may be helped to

111 Hopkins, op. cil., p. 192 ; Geiger, op. cit., vol. i., p. 221 ; Warren, op. cit., p. 43; Manu, iii., 186, iv. 231 ; Harsa-Carita of Banna (trans. E. B. Cowell and F. W. Thomas), p. 197 ; Vishnu Purana (ed. H. H. Wilson, 1840), p. 431 ; Gazetteer of the Bombay Presidency, vol. i., Pt. i., p. 25.

$$
111 \text { i., lxx., } 35 . \quad 112 x ., 62 \text {; v. } 95 .
$$

11 "See my paper, "Rajputs and Mahrattas," The Journal of the Koyal Anthropological Institute, vol. xl., pp. 39 et seq.

${ }^{116}$ Muir, op. cit., pt. i., pp. 45, 75, 87, 96 et seq., 156, 201.

116 Manu, viii, , 325. 


\section{The Veneration of the Cow in India. 303}

understand the Buddhist attitude towards the cow. This new faith was in its original anti-Brahmanical, and it substituted for the special reverence for one sacred beast, the cow, a general tenderness for all animal life. But the use of animal food among the lower strata of the people was probably too strongly established to render a general prohibition possible. We may compare with this the Sikh revolt against Brahmanism. The great Sikh Guru, Hargobind, like the Āryā Samãj, which has as its object the restoration of Vedic observances as opposed to the later Brahmanical ritual, shows indifference to the cow. The Sikhs do not regard the cow as specially sacred, save where they have come under Brahman influence, though they so far concede to Hindu prejudice that they believe the slaughter of it to be more heinous than that of any other animal.117

Naturally, then, when Brahmanism rose to power on the decay of Buddhism, the cow became closely associated with it.

In the first place, the chief agents of the dissemination of the new doctrine were the wandering ascetics, who forced their way through the forest region dividing the Holy Land of Brahmanism in the north from the south country, the home of the Dravidian tribes. For these missionaries the cow was necessary as a source of food and to provide the butter which, as a substitute for animal victims, now came to be used in the fire sacrifice. The adoption of the word gotra, a "cow-pen," to define the Brahmanical groups for the purpose of marriage, shows the importance of the animal in their social economy.

Secondly, as among various races, including the IndoAryans and Iranians, the cow was identified with Mother Earth, while the bull represented the spirit of fertility. ${ }^{118}$ In

${ }^{117}$ M. A. Macauliffe, The Sikh Religion, vol. iv., p. 220 n.; II. A. Rose, op. cit., vol. ii, p. 23.

${ }^{210} \mathrm{~J}$. A. MacCulloch, The K'cligion of the Ancient Celts, pp. 38, 140, 205 ; L. R. Farnell, Cults of the Greek States, vol. v., p. 126. 


\section{The Veneration of the Cow in India.}

its Brahmanical form the legend was localised at Gokarn, a sacred place on the western coast, where Siva, at the prayer of the Earth goddess, rose through the ear of a cow whose form she had assumed. ${ }^{119}$

Thirdly, the cow was associated with the new cultus. The bull became the attendant of Siva, lord of fertility, the favourite object of Brahman worship, whose sacred marriage with the Earth goddess is periodically celebrated. On the same principle the Brahmans recognised and adopted the worship of Krishna, who in one of his many forms was a god of cattle, and devotion and tendance of the cow is a prominent part of his cultus. ${ }^{120}$ The cow was introduced into the family ritual conducted under Brahman superintendence. Thus the sacred marriage of the bull and cow is performed as a mimetic fertility charm at marriage, and at the death rites to strengthen the puny soul for its journey to the world of spirits.

Lastly, the Muhammadan raids and the slaughter of the cow at the Idu-'l-azha festival must have tended to increase the devotion towards the animal. The Muhammadan chronicles tell many stories of deliberate cow slaughter in the lust of conquest, with a view to enforce the submission of the Hindus, or in revenge for their resistance. ${ }^{121}$ Even as late as 1813 , it is alleged by the Hindus of Benares that the Muhammadans, in the course of a fanatical riot, slew a cow and her calf and poured their blood upon the sacred stone pillar, the Laat Bhairon, which up to that date had withstood all attempts to destroy it. Now in horror at the outrage it trembled and fell to pieces. ${ }^{122}$

To sum up the suggestions which I have ventured to advance in this paper:-We find the cow domesticated and

119 Gazetteer of the Bombay Presidency, vol. xv., pt. ii., pp. 288-9 $n 2$.

${ }^{120} \mathrm{~J}$. Kennedy, "The Child Krishna, Christianity, and the Gujars," The Journal of the Royal Asiatic Society, Oct. 1907, pp. $95 \mathrm{I}$ et seq. .

121 Sir. H. Elliot, History of India, vol. i., pp. 193, 298.

${ }^{122} \mathrm{H}$. II. Wilson, History of India from $180 \mathrm{~g}$ to 1835 , vol. i., p. $472 \mathrm{n}$. 


\section{The Veneration of the Cow in India. 305}

regarded as taboo or "sacred," not necessarily a totem, from that very early period when the Indo-Aryans and their kinsmen the Iranians still formed one united community. At this stage of culture the kinship of man with the animal world, and particularly with the domesticated cattle of the tribe, was fully recognised; and, as is not uncommon with tribes in the pastoral or agricultural stage of culture, the kinsmen by the periodical sacrifice and ritualistic eating of the flesh of the sacred animal sought to gain communion with the divine. In later days, when the foreigner, an eater of beef, entered the land and became to some extent Hinduized, it became unnecessary for him to abandon his usual food, because its consumption had now acquired a local ritualistic sanction. We have seen that traces of this communal sacrifice may still be traced among the Kafirs, and particularly among the Todas, and that the rite is still performed in effigy by certain castes or tribes. Gradually, for reasons which are at present obscure, a feeling of humanitarianism spread through northern India, which resulted in the restriction of blood sacrifices and the sacramental eating of the victim. But the use of beef was not immediately discontinued among the imperfectly Hinduized foreigners, and still holds its ground among the menial and forest tribes. If this view be accepted, it supplies an interesting parallel to the theory of Professor Ridgeway, ${ }^{123}$ that the flesh-roasting and flesh-eating Achæans were a foreign tribe which migrated from northern Europe into Greece. The association of Buddhism with the Kshatriya or warrior group helps to furnish an explanation of the comparative indifference of the new faith towards the Brahman cult of the cow. With the rise of the neoBrahmanism the protection and veneration of the cow were revived and extended. The cult of Mother Earth now adopted into orthodox beliefs, the ascetic missionary organisation, the introduction of the worship of Siva with the 123 The Early Age of Greece, vol. i., p. 524. 
306 The Veneration of the Cow in India.

bull as his attendant, the rise of the cult of Krishna, the adoption of the animal into the domestic ritual conducted under Brahman supervision,--these were all developments of the same movement, which ended in the adoption of the sanctity of the cow as one of the chief bonds of connection between the many rival sects, each provided with its own body of dogma and ritual, which now form the amorphous mass of beliefs constituting Hinduism as we observe it at the present day.

In the death struggle which orthodox Hinduism is now waging against the intrusive Western culture, the beliefs we have been considering will doubtless play a prominent part. But this is a matter for the statesman, not for the student of comparative religion.

W. CROOKE. 